\title{
Profil Kreativitas dalam Pemecahan Masalah Matematika Ditinjau dari Gaya Kognitif Field Independent (FI) dan Field Dependent (FD) Siswa Kelas VIII A SMP Negeri 12 Jember Profile of Creativity in Mathematics Problem Solving Based on Field Independent (FI) and Field Dependent (FD) Cognitive Style Student at Class VIII A of SMP Negeri 12 Jember
}

\author{
Risky Cahyo Purnomo, Sunardi, Titik Sugiarti \\ Program Studi Pendidikan Matematika, Jurusan Pendidikan MIPA, Fakultas Keguruan dan Ilmu \\ Pendidikan, Universitas Jember (UNEJ) \\ Jln. Kalimantan 37, Jember 68121 \\ E-mail: sunardifkipunej@yahoo.com
}

\begin{abstract}
Abstrak
Tujuan penelitian ini adalah untuk mendeskripsikan tingkat kreativitas dalam pemecahan masalah matematika. Penelitian ini termasuk jenis penelitian deskriptif dan menggunakan pendekatan kualitatif. Subjek penelitian sebanyak 7 siswa kelas VIII A SMP Negeri 12 Jember yang dikelompokkan berdasarkan gaya kognitif menggunakan instrumen Group Embedded Figures Test (GEFT), dengan rincian 4 siswa field independent dan 3 siswa field dependent. Metode pengumpulan data dalam penelitian ini adalah tes kemampuan berpikir kreatif dan wawancara. Penelitian ini menggunakan triangulasi waktu, yaitu dengan membandingkan data yang diperoleh dari tes kemampuan berpikir kreatif dan wawancara pertama dan tes kemampuan berpikir kreatif dan wawancara kedua. Hasil tes kemampuan berpikir kreatif melalui pemecahan masalah matematika dikelompokkan berdasarkan karakteristik berpikir kreatif, yaitu kelancaran, keluwesan, dan kerincian. Tingkat kreativitas atau disebut Tingkat Berpikir Kreatif (TBK) dikategorikan menjadi 5 tingkatan, yaitu TBK 4 (sangat kreatif), TBK 3 (kreatif), TBK 2 (cukup kreatif), TBK 1 (kurang kreatif), dan TBK 0 (tidak kreatif). Tingkat kreativitas yang dapat diidentifikasi dalam penelitian ini adalah 1 siswa field independent dinyatakan sangat kreatif (TBK 4) dan 3 siswa field independent dinyatakan kreatif (TBK 3). Untuk siswa field dependent, tingkat kreativitas yang dapat diidentifikasi adalah 1 siswa dinyatakan kreatif (TBK 3), 1 siswa dinyatakan cukup kreatif (TBK 2), dan 1 siswa dinyatakan kurang kreatif (TBK 1). Hasil ini menunjukkan bahwa siswa field independent cenderung lebih memiliki kreativitas dibanding siswa field dependent dalam pemecahan masalah matematika.
\end{abstract}

Kata Kunci: berpikir kreatif, gaya kognitif field independent, gaya kognitif field dependent, pemechan masalah.

\section{Abstract}

The purpose of this research is to describe level of creativity in mathematics problem solving. it is descriptive research that used qualitative approach. The Subject are 7 students of SMP Negeri 12 Jember in class VIII A. They are grouped by cognitive style that used Group Embedded Figures Test (GEFT). They are 4independent students and 3 dependent students. The method of Data collection this research iscreative thinking ability test and interviews. This Research used a triangulation of time. That was compared by data collection from the first creative thinking ability test and interview and the second creative thinking ability test and interview. Creativity in problem solving mathematics had grouped based on the characteristics of creative thinking they are fluency, flexibility, and elaboration.The level of creativity was called TBK categorized into five levels, namely TBK 4 (very creative), TBK 3 (creative), TBK 2 (quite creative), TBK 1 (less creative), and TBK 0 (not creative). The level of creativity that can be identified in this research there is One person of independent students expressed very creative (TBK 4) and Three person of independent students expressed creative (TBK 3). Whereas students of dependent, the level of creativity that can be identified is one student expressed creative (TBK 3), one student stated quite creative (TBK 2), and one student expressed less creative (TBK 1). These results indicate that independent students tend to have more creatively than dependent students in mathematical problem solving.

Keywords: creative thinking, field independent cognitive style, field dependent cognitive style, problem solving.

\section{Pendahuluan}

Ilmu pengetahuan dan teknologi berkembang pesat. Perkembangan itu pastinya akan diikuti oleh tantangan yang semakin rumit. Untuk itu diperlukan suatu alat yang dapat menjawab tantangan tersebut yaitu pendidikan. Pendidikan nasional bertujuan untuk mengembangkan potensi siswa agar 
menjadi manusia yang beriman dan bertakwa kepada Tuhan Yang Maha Esa, berakhlak mulia, sehat, berilmu, cakap, kreatif, mandiri, dan menjadi warga negara yang demokratis serta bertanggungjawab. Badan Standar Nasional Pendidikan [2] menyebutkan bahwa Kurikulum Tingkat Satuan Pendidikan (KTSP) dikembangkan berdasarkan prinsip bahwa peserta didik memiliki posisi sentral untuk mengembangkan kemampuan yang dimilikinya. Salah satu kemampuan tersebut adalah kemampuan berpikir kreatif. Kemampuan berpikir keatif merupakan potensi yang dimiliki oleh setiap manusia, namun yang berbeda adalah tingkatannya. Kemampuan ini perlu dikembangkan agar peserta didik dapat bertahan dan mengikuti berbagai bentuk perubahan, serta dapat bersaing dalam dunia yang semakin kompetitif.

Matematika sebagai salah satu ilmu dasar memiliki peranan penting dalam perkembangan ilmu dan teknologi. Matematika juga dapat menuntun siswa untuk berpikir logis, analitis, sistematis, kritis, dan kreatif. Belajar matematika dapat melatih siswa belajar bernalar secara kritis, kreatif, dan aktif. Sehubungan dengan ini, Hobri [3] mengemukakan bahwa penguasaan materi matematika oleh siswa menjadi keharusan yang tidak bisa ditawar lagi, terutama di dalam penataan nalar dan pengambilan keputusan dalam era persaingan yang kompetitif. Oleh karena itu, matematika menjadi salah satu pelajaran wajib disetiap jenjang pendidikan. Melalui pembelajaran matematika, guru diharapkan dapat melatih cara berpikir siswa dalam menarik kesimpulan, mengembangkan aktivitas kreatif, mengembangkan kemampuan pemecahan masalah, dan mengembangkan kemampuan menyampaikan informasi secara matematis. Hal tersebut menjadikan kemampuan berpikir siswa akan terasah dengan pemberian tugas pemecahan masalah.

Kemampuan berpikir siswa dapat dikembangkan melalui pemecahan masalah. Dalam pembelajaran matematika kreativitas sangat dibutuhkan dalam menyelesaikan soal-soal yang melibatkan siswa untuk berpikir kreatif, yaitu siswa diharapkan dapat menemukan ide-ide kreatif dalam menganalisa dan menyelesaikan soal Cara siswa dalam mengemukakan ide-ide kreatifnya berbeda-beda, hal ini dikarenakan kemampuan berpikir yang dimiliki siswa berbeda pula. Oleh karena itu, dalam memecahkan masalah matematika, setiap siswa memiliki cara dan gaya berfikir yang berbeda-beda. Strategi pemecahan masalah matematika dipengaruhi oleh cara siswa dalam memproses, menyimpan, maupun menggunakan informasi untuk menanggapi suatu masalah tersebut. Dalam dunia pendidikan hal ini disebut gaya kognitif. Argarini [1] mengemukakan gaya kognitif merupakan karakteristik individu dalam berpikir, merasakan, mengingat, memecahkan masalah dan membuat keputusan.

Gaya kognitif dapat dibedakan atas beberapa cara pengelompokan, menurut Usodo [5] salah satu cara pengelompokannya adalah berdasarkan perbedaan psikologis siswa dalam menghadapi situasi lingkungannya. Berdasarkan pengelompokan ini gaya kognitif dibedakan atas gaya kognitif Field Independent (FI) dan gaya kognitif Field Dependent (FD). Siswa bergaya kognitif FI merupakan karakteristik individu yang mampu menganalisis dalam memisahkan unsur-unsur dari konteksnya secara lebih analitik. Siswa bergaya kognitif FD merupakan karakteristik individu yang memproses informasi secara global sehingga persepsinya mudah terpengaruh oleh perubahan lingkungan. Siswa bergaya kognitif FI memiliki kemampuan dalam menganalisis informasi tidak terstruktur dan dapat mengorganisasikan untuk memecahkan masalah. Siswa bergaya kognitif FD cenderung memerlukan intruksi atau petunjuk yang lebih jelas mengenai bagaimana memecahkan masalah. Hal itu dapat menjadi gambaran bagi guru bahwa beberapa siswa mungkin membutuhkan bantuan dalam menentukan konsep penting dari materi yang diajarkan. Guru dapat menentukan strategi mengarahkan siswa menuju ke tingkat berpikir yang lebih tinggi dengan tujuan lebih dapat memahami materi yang diberikan. Berdasarkan hal tersebut akan dilakukan penelitian tentang tingkatan berpikir kreatif siswa berdasarkan masing-masing gaya kognitifnya.

Penelitian Sasongko dan Siswono [8] diperoleh simpulan yaitu ditinjau dari gaya kognitif field independent diperoleh hasil subjek FI memenuhi ketiga komponen kreativitas yang telah ditetapkan, yaitu kefasihan, fleksibilitas, dan kebaruan. Oleh karena itu, kreativitas subjek FI adalah sangat kreatif. Ditinjau dari gaya kognitif field dependent, hasil penelitian menunjukkan subjek FD tidak mampu memenuhi ketiga komponen kreativitas. Dua subjek FD dapat memenuhi komponen kefasihan saja dan satu subjek FD yang lain tidak dapat memenuhi ketiga komponen kreativitas. Oleh karena itu, kreativitas subjek FD adalah kurang kreatif atau bahkan tidak kreatif. Hasil penelitian tersebut menjadi salah satu pertimbangan dalam penelitian ini. Namun penelitian ini fokus pada pemecahan masalah matematika.

\section{Metode Penelitian}

Penelitian ini termasuk jenis penelitian deskriptif. Sukardi [9] menyatakan bahwa penelitian deskriptif pada umumnya dilakukan dengan tujuan utama, yaitu menggambarkan secara sistematis fakta dan karakteristik objek atau subjek yang diteliti secara tepat. Penelitian ini menggunakan pendekatan kualitatif karena data yang dikumpulkan akan dipaparkan dalam bentuk kata-kata yang dirangkai dalam sebuah kalimat, tidak berupa angka atau nilai saja. Analisis yang digunakan bersifat deskriptif analitik yang berarti interpretasi terhadap isi dibuat dan disusun secara sistemik/menyeluruh dan sistematis.

Subjek dalam penelitian ini adalah siswa kelas VIII A SMP Negeri 12 Jember yang dikelompokkan berdasarkan gaya kognitifnya menggunakan instrumen Group Embedded Figures Test (GEFT). Norman et all [4] pengelompokan tersebut ditentukan dengan melihat skor yang diperoleh siswa yaitu siswa yang skornya lebih dari $50 \%$ dari skor maksimal, dikelompokkan sebagai siswa yang memiliki gaya kognitif field independent dan siswa yang skornya kurang dari atau sama dengan $50 \%$ dari skor maksimal, dikelompokkan sebagai siswa yang memiliki gaya kognitif field dependent. Subjek yang diambil berjumlah 7 siswa dengan rincian 4 siswa bergaya kognitif field independent dan 3 siswa bergaya kognitif field dependent. Selanjutnya siswa akan diberi tes pemecahan masalah untuk menentukan 
tingkat kreativitasnya. Untuk mempermudah pelaksanan penelitian, diperlukan alur penelitian dengan tahapantahapan sebagai berikut.

a) Kegiatan Pendahuluan

Melakukan tes gaya kognitif field independent dan field dependent kepada subjek penelitian untuk mengetahui gaya kognitif yang dimilikinya, sehingga subjek penelitian dapat dikelompokkan sesuai gaya kognitifnya. Instrumen yang digunakan adalah GEFT (Group Embedded Figures Test) yang diadaptasi dari Philiph K. Oltman Eveelyn dan Herman A. Witkin.

b) Pembuatan Instrumen Penelitian

Instrumen penelitian merupakan alat bantu yang digunakan oleh peneliti untuk mengumpulkan data penelitian dengan cara melakukan pengukuran [10]. Lebih lanjut Mustafa [7] menyatakan bahwa instrumen adalah alat pengukur variabel. Instrumen penelitian yang digunakan pada penelitian ini yaitu peneliti, tes, pedoman wawancara, dan lembar validasi tes maupun pedoman wawancara.

c) Memvalidasi Instrumen

Validitas suatu instrumen penelitian adalah derajat yang menunjukkan dimana suatu tes mengukur apa yang hendak diukur [9]. Uji validitas dilakukan dengan memberikan lembar validasi kepada tiga orang validator, yaitu dua dosen Pendidikan Matematika dan seorang guru matematika SMP Negeri 12 Jember.

d) Menganalisis data yang diperoleh dari lembar validasi dan kemudian merevisi instrumen berdasarkan hasil analisis tersebut. Jika instrumen valid, dilanjutkan ke uji reliabilitas dan jika instrumen tidak valid maka dilakukan merevisi tes dan uji validitas kembali.

e) Uji Reliabilitas

Reliabilitas sama dengan konsistensi atau keajegan. Sukardi [9] menyatakan bahwa suatu instrumen penelitian dikatakan mempunyai nilai reliabilitas yang tinggi, apabila tes yang dibuat mempunyai hasil yang konsisten dalam mengukur yang hendak diukur. Penelitian ini menggunakan tipe konsistensi internal, yaitu dengan melihat apakah butir-butir tugas dapat berfungsi secara sama untuk mengidentifikasi indikatorindikator kemampuan berpikir kreatif. Derajat reliabilitas tidak diukur secara numerik, karena bentuk tugas berupa tugas kinerja yang tidak diskor. Hasil tugas yang diperhatikan adalah apakah siswa dapat menunjukkan indikator berpikir kreatif (kelancaran, keluwesan, kerincian) atau tidak. Uji reliabilitas dilakukan di kelas selain kelas yang menjadi subjek penelitian, yaitu kelas VIII B.

f) Menganalisis data yang diperoleh dari uji reliabilitas. Jika memenuhi kriteria instrumen yang reliabel maka dilanjutkan ke tahap selanjutnya. Jika tidak, maka akan dilakukan revisi dan uji reliabilitas kembali.

g) Mengumpulkan Data

Cara memperoleh data dalam penelitian ini menggunakan metode tes dan wawancara. Tes yang digunakan dalam penelitian ini adalah tes kognitif dan tes kemampuan berpikir kreatif yang berupa soal pemecahan masalah matematika. Tes kognitif dilaksanakan terlebih dahulu untuk mengetahui gaya kognitif yang dimiliki siswa, bergaya kognitif field independent atau field dependent. Dilanjutkan melaksanakan tes kemampuan berpikir kreatif untuk mengukur tingkat kreativitas siswa yang telah digolongkan menurut gaya kognitifnya. Selanjutnya hasil tes kemampuan berpikir kreatif dikelompokkan berdasarkan indikator berpikir kreatif, yaitu kelancaran, keluwesan, dan kerincian. Wawancara pada penelitian ini berguna untuk menggali informasi lebih mendalam mengenai tingkat kreativitas siswa. Jenis wawancara yang digunakan dalam penelitian ini adalah wawancara semi terstruktur.

h) Triangulasi Data

Triangulasi adalah teknik pemeriksaan keabsahan data yang memanfaatkan sesuatu yang lain di luar data itu untuk pengecekan atau sebagai pembanding terhadap data itu [6]. Pada penelitian ini menggunakan triangulasi waktu, yaitu dengan membandingkan data yang diperoleh dari tes kemampuan berpikir kreatif dan wawancara pertama dan tes kemampuan berpikir kreatif dan wawancara kedua.

Analisis Data

Setelah semua data terkumpul, baik data hasil tes berpikir kreatif siswa maupun hasil wawancara selanjutnya data tersebut dianalisis dengan tahapan sebagai berikut. (1) Tahap reduksi data, Inti dari tahap ini adalah menyusun, menyeleksi dan membuang data yang tidak diperlukan sehingga data yang terpilih dapat diproses ke langkah selanjutnya. (2) Tahap penyajian data, data disajikan dalam bentuk naratif. Hasil tes kemampuan berpikir kreatif melalui pemecahan masalah dikelompokkan berdasarkan karakteristik berpikir kreatif, yaitu kelancaran, keluwesan, dan kerincian. Selanjutnya mengkategorikan siswa ke dalam tingkat kreativitas. Pengkategorian tersebut berdasarkan karakteristik berpikir kreatif sesuai Tabel 1 berikut.

Tabel 1. Tingkat Kreativitas

\begin{tabular}{|l|l|}
\hline \multicolumn{2}{|c|}{ Tabel 1. Tingkat Kreativitas } \\
\hline TBingkat Kreativitas & \multicolumn{1}{|c|}{ Kriteria Berpikir Kreatif } \\
\hline TBK 3 (Kreatif) & $\begin{array}{l}\text { kelancaran, keluwesan, } \\
\text { kerincian }\end{array}$ \\
\hline TBK 2 (Cukup Kreatif) & $\begin{array}{l}\text { kelancaran dan keluwesan, } \\
\text { atau } \\
\text { kelancaran dan kerincian, } \\
\text { atau } \\
\text { keluwesan dan kerincian }\end{array}$ \\
\hline TBK 1 (Kurang Kreatif) & $\begin{array}{l}\text { Kelancaran, atau } \\
\text { keluwesan }\end{array}$ \\
\hline TBK 0 (Tidak Kreatif) & tidak memenuhi seluruhnya \\
\hline
\end{tabular}

j) Kesimpulan

Menyimpulkan data dari hasil penelitian sesuai dengan permasalahan dan tujuan penelitian. Kesimpulan berdasarkan hasil analisis informasi atau temuan-temuan yang diperoleh dalam penelitian. Untuk mempermudah tahap penyimpulan data, siswa diberi keterangan FI-1, FI2, FI-3, dan seterusnya untuk siswa bergaya kognitif field 
independent, sedangkan siswa bergaya kognitif field dependent diberi keterangan FD-1, FD-2, FD-3, dan seterusnya.

\section{Hasil Penelitian dan Pembahasan}

Sebelum tes kemampuan berpikir kreatif diberikan, dilakukan uji validitas terhadap tes. Perhitungan hasil validasi oleh validator diperoleh nilai $\mathrm{Va}=4,57$ yang berarti bahwa tingkat kevalidan tes adalah valid. Banyaknya soal yang divalidasi oleh validator sebanyak 4 soal. Keempat soal tersebut dibagi menjadi 2 kelompok, yaitu 2 soal untuk tes tahap pertama dan 2 soal untuk tes tahap kedua. Tes tahap kedua berfungsi untuk memverifikasi hasil tes tahap pertama. Langkah selanjutnya adalah uji reliabilitas dilakukan di kelas VIII B yang diikuti oleh 34 siswa. Setelah tes diberikan kepada siswa, hasil tes diklasifikasikan ke dalam lima tingkatan kemampuan berpikir kreatif berdasarkan kriteria kelancaran, keluwesan, dan kerincian. Berdasarkan rekap pengklasifikasian yang diperoleh, tes kemampuan berpikir kreatif dalam penelitian ini dinyatakan reliabel untuk digunakan dalam pengumpulan data, karena dapat mengidentifikasi kriteria kemampuan berpikir kreatif siswa. Berdasarkan rekap di kelas VIII B dengan jumlah siswa 34 orang, diperoleh data 3 siswa dinyatakan sangat kreatif, 9 siswa dinyatakan kreatif, 6 siswa dinyatakan cukup kreatif, 5 siswa dinyatakan kurang kreatif, dan 13 siswa dinyatakan tidak kreatif. Selanjutnya tes tersebut diberikan kepada subjek penelitian.

Subjek penelitian yaitu siswa kelompok Field Dependent (FD) dan kelompok Field Independent (FI) yang telah terpilih mengikuti Tes Kemampuan Berpikir Kreatif pada waktu yang telah ditentukan. Hasil pekerjaan mereka kemudian dikategorikan ke dalam lima tingkatan kreativitas berdasarkan kriteria berpikir kreatif (kelancaran, keluwesan, dan kerincian) yang dimiliki masing-masing siswa, yaitu TBK 0 (tidak kreatif), TBK 1 (kurang kreatif), TBK 2 (cukup kreatif), TBK 3 (kreatif), dan TBK 4 (sangat kreatif). Langkah selanjutnya adalah melakukan wawancara dengan siswa secara individu untuk memferivikasi hasil tes yang telah dilaksanakan sebelumnya.

Tingkat kreativitas yang dapat diidentifikasi dalam penelitian ini adalah 1 siswa FI dinyatakan sangat kreatif (TBK 4) dan 3 siswa FI dinyatakan kreatif (TBK 3). Untuk siswa field dependent, tingkat kreativitas yang dapat diidentifikasi adalah 1 siswa dinyatakan kreatif (TBK 3), 1 siswa dinyatakan cukup kreatif (TBK 2), dan 1 siswa dinyatakan kurang kreatif (TBK 1).

Berdasarkan analisis data yang dilakukan sebelumnya diperoeh data sebagai berikut, 1 siswa field independent dinyatakan sangat kreatif karena mampu memenuhi ketiga kriteria berpikir kreatif yang ditetapkan, yaitu kelancaran, keluwesan, dan kerincian, sedangkan 3 siswa sisanya dikatakan kreatif. Sesuai dengan hasil analisis data dan triangulasi data, keempat siswa field independent mampu memenuhi kriteria kerincian, hal ini dapat dilihat di pekerjaan mereka yang menuliskan langkah-langkah penyelesaian soal dengan sistematis dan detail. Siswa menggunakaan rumus-rumus yang sesuai untuk menyelesaikan soal yang diberikan. Saat pengerjaan soal, siswa field independent terlihat berkonsentrasi. Dari hasil wawancara mereka mengatakan bahwa telah memahami maksud dari soal sehingga tidak ada pertanyan yang diajukan kepada peneliti terkait soal yang diberikan. Untuk kriteria kelancaran, tidak semua siswa field independent mampu memenuhinya. Ada 3 siswa yang berhasil memenuhi kriteria tersebut, dengan rincian 2 siswa TBK 3 dan 1 siswa TBK 4. Hal ini dapat dilihat dalam pekerjaan mereka yang mampu memberikan banyak jawaban berbeda terhadap suatu permasalahan yang diberikan sesuai dengan batas minimal yang ditentukan. Jawaban yang diberikan mereka seluruhnya menggunakan bilangan bulat. Dari hasil wawancara, ketiga siswa ini mengatakan hal yang sama, yaitu hanya bilangan bulat yang ada di pikiran mereka. Ketika peneliti menanyakan bilangan lain yang menghasilkan jawaban yang sama, mereka masih memerlukan waktu untuk berpikir. Sebagian dari mereka, yaitu FI-3 bisa memberikan jawaban yang dimaksud peneliti yaitu menggunakan bilangan desimal dalam memberikan jawaban yang lain tersebut. Karena itu FI-3 mengatakan bahwa masih banyak jawaban berbeda yang dapat diberikan. Namun FI-1 dan FI-4 harus diberi arahan oleh peneliti, lalu mereka dapat memberikan jawaban yang dimaksud oleh peneliti. Kriteria keluwesan dipenuhi oleh 2 siswa field independent. Kedua siswa tersebut dapat memberikan dua cara berbeda untuk menyelesaikan masalah yang diberikan. Siswa field independent berpendapat bahwa mencari cara penyelesaian yang berbeda membutuhkan waktu karena mereka harus berpikir cara yang berbeda dengan cara yang telah digunakan sebelumnya.

Untuk siswa field dependent, dari hasil analisis data yang dilakukan sebelumnya diperoleh data sebagai berikut, 1 siswa field dependent dikatakan kreatif, 1 siswa dikatakan cukup kreatif, dan 1 siswa sisanya dikatakan kurang kreatif. Subjek FD-1, FD-2, dan FD-3 tidak ada yang dapat memenuhi ketiga kriteria berpikir kreatif yang ditetapkan, yaitu kelancaran, keluwesan, dam kerincian. FD-1 dikatakan lancar dalam memecahkan permasalahan karena mampu memberikan jawaban berbeda yang banyaknya sesuai dengan batas minimal yang ditentukan. Jawaban yang diberikan pun bernilai benar. FD-1 juga memberikan penyelesaian masalah dengan langkah-langkah yang detail dan sistematis, sehingga dikatakan memenuhi kriteria kerincian. Namun subjek yang menempati tingkat kreativitas ketiga ini tidak dapat memberikan penyelesaian masalah lebih dari satu cara berbeda. Oleh karena itu FD-1 dikatakan tidak luwes dalam memecahkan masalah matematika. Untuk subjek FD-2 hanya berhasil menempati tingkat kreativitas kedua, karena hanya mampu memenuhi kriteria kelancaran dalam tes kemampuan berpikir kreatif tahap pertama. Namun pada saat tes yang kedua, FD-2 hanya mampu memenuhi kriteria keluwesan. Dari kedua tahap tes kemampuan berpikir kreatif yang telah dikerjakan, FD-2 tidak dapat memenuhi kriteria kerincian. Hal ini dapat terlihat dalam pekerjaannya. FD-2 tidak detail dalam menggunakan rumus, yaitu FD-2 mengunakan rumus luas bangun trapesium padahal luas yang ingin subjek cari adalah luas bangun jajargenjang. Subjek FD-2 juga tidak detail dalam memberikan ukuran panjang sepasang sisi sejajar pada trapesium. Ukuran panjang sepasang sisi sejajar pada trapesium tidak kongruen, sedangkan FD-2 memberikan 
ukuran yang kongruen. Hal itulah yang membuat subjek FD2 dikatakan tidak rinci.

Namun untuk subjek FD-3 menempati tingkat kreativitas kesatu karena hanya memenuhi kriteria kerincian saja. Dua kriteria berpikir kreatif tidak dapat dipenuhi. Dari hasil wawancara, FD-3 mengatakan bahwa hanya jawaban itu yang ada dalam pikirannya, sulit untuk mencari jawaban ataupun cara yang berbeda.

Saat pelaksanaan tes kemampuan berpikir kreatif berlangsung, baik ada tahap pertama ataupun yang kedua tidak ada satu pun siswa field independent meminta arahan pada peneliti ataupun berdiskusi dengan teman yang lain. Siswa field independent cenderung memilih berkonsentrasi dan mengerjakan sendiri tanpa menghiraukan keadaan sekitar. Berbeda dengan siswa field dependent, mereka terlihat gelisah dan perlu arahan yang lebih untuk memecahkan masalah matematika yang diberikan. Mereka sesekali berdiskusi dengan teman yang lain untuk bertanya rumus atau hanya membandingkan jawaban mereka. Saat diwawancara mereka mengatakan bahwa soal yang diberikan mudah namun mereka lupa rumusnya sehingga mereka bertanya kepada teman. Tidak konsentrasinyá dalam mengerjakan membuat mereka kurang detail dalam menjawab soal. Akibatnya saat pengoreksian terlihat jawaban yang diberikan kurang maksimal.

Temuan dalam penelitian ini, siswa field independent lebih baik dalam memecahkan masalah matematika/ Siswa field independent menunjukkan kesungguhan dalam memecahkan masalah. Mereka menggunakan beragam cara dalam upaya memecahkan masalah matematika. Saat mengerjakan soal siswa field independent berkonsentrasi penuh sehinga dihasilkan jawaban yang memuaskan. Hal ini menjadikan siswa field independent dapat menempati tingkatan kreativitas yang tinggi, karena sebagian besar kriteria kemampuan berpikir kreatif dapat mereka penuhi. Hal ini relevan dengan penelitian Sasongko (2013) yang menyimpulkan bahwa kreativitas subjek field independent adalah sangat kreatif. Namun temuan yang diperoleh untuk siswa field dependent dalam memecahkan masalah matematika kurang menunjukkan kesungguhan. Siswa field dependent masih memerlukan arahan yang lebih dalam memecahkan masalah matematika baik oleh peneliti ataupun berdiskusi dengan temannya. Siswa field dependent cenderung menerima struktur yang sudah ada dan kesulitan untuk merekonstruksi strategi pemecahan masalah yang sebelumnya telah digunakan. Temuan lain dalam penelitian ini, siswa field dependent ada yang masuk dalam kategori siswa kreatif (TBK 3). Subjek dapat memberikan beberapa jawaban yang berbeda secara detail dan sistematis, namun untuk menyelesaikannya, subjek banyak bertanya. Hal ini menunjukkan bahwa tidak semua siswa field dependent dinyatakan kurang kreatif.

\section{Penutup}

\section{Kesimpulan}

Berdasarkan hasil analisis dan pembahasan berkaitan dengan profil kreativitas pemecahan masalah siswa field independent (FI) maupun siswa field dependent (FD), dapat diambil kesimpulan sebagai berikut. Siswa kelas VIII A di
SMP Negeri 12 Jember yang bergaya kognitif field independent memiliki tingkatan kreativitas keempat dan ketiga, yaitu kreativitas subjek FI dalam pemecahan masalah matematika aspek geometri adalah sangat kreatif dan kreatif. Sebanyak 1 siswa dinyatakan sangat kreatif, mampu memecahkan masalah matematika dengan lancar, luwes, dan rinci. Sebanyak 3 siswa dinyatakan kreatif dengan rincian 2 siswa mampu memecahkan masalah matematika dengan lancar dan rinci, dan 1 siswa mampu memecahkan masalah matematika dengan luwes dan rinci. Subjek FI-3 dinyatakan sangat kreatif, sedangkan subjek FI-1, FI-2, dan FI-4 dinyatakan kreatif.

Siswa kelas VIII A di SMP Negeri 12 Jember yang bergaya kognitif field dependent memiliki tingkatan kreativitas ketiga, kedua, dan kesatu, yaitu subjek FD dalam pemecahan masalah matematika aspek geometri adalah kreatif, cukup kreatif, dan kurang kreatif. Sebanyak 1 siswa dinyatakan kreatif, mampu memecahkan masalah matematika dengan lancar dan rinci, 1 siswa dinyatakan cukup kreatif, mampu memecahkan masalah matematika dengan lancar, dan 1 siswa dinyatakan kurang kreatif, mampu memecahkan masalah matematika dengan rinci. Subjek yang dinyatakan kreatif adalah FD-1, FD-2 dinyatakan cukup kreatif, sedangkan FD-3 dinyatakan kurang kreatif.

Saran

Berdasarkan hasil penelitian yang telah didapatkan, ada beberapa saran yang bisa diberikan yaitu sebagai berikut.

1) Hasil penelitian menunjukkan adanya persamaan dan perbedaan profil pemecahan masalah matematika siswa bergaya kognitif field independent dan field dependent sehingga direkomendasikan kepada guru matematika untuk memperhatikan temuan tersebut dalam menyusun rencana pembelajaran di kelas.

2) Soal pemecahan masalah terbuka sebaiknya lebih sering diberikan kepada siswa agar siswa terbiasa mengerjakan soal pemecahan masalah.

3) Soal pemecahan masalah terbuka sebaiknya lebih sering diberikan kepada siswa agar siswa terbiasa mengerjakan soal pemecahan masalah.

4) Agar temuan lebih bervariasi diharapkan untuk mengadakan penelitian sejenis dengan subjek yang lebih banyak dan atau dengan gaya kognitif lain.

5) Pembuatan soal tes kemampuan berpikir kreatif bukan hanya memperhatikan kesesuaian materi, namun juga penggunaan bahasa pada soal. Bahasa padasoal yang sesuai akan membuat siswa atau subjek mudah memahami soal yang diberikan.

\section{Ucapan Terima Kasih}

Paper disusun untuk memenuhi syarat memperoleh gelar sarjana (S1) pada Program Studi Pendidikan Matematika Fakultas Keguruan dan Ilmu Pendidikan Universitas Jember. Penulis R. C. P. mengucapkan terima kasih kepada dosen pembimbing tugas akhir yang telah membimbing selama penelitian, dosen penguji yang telah memberikan saran dan kritik, validator yang telah bersedia 
memvalidasi instrumen yang digunakan dalam penelitian ini, pihak SMP Negeri 12 Jember yang telah mengijinkan peneliti untuk melakukan penelitian, dan siswa-siswi SMP Negeri 12 Jember kelas VIII A yang telah bersedia menjadi subjek penelitian.

\section{Daftar Pustaka}

[1] Argarini, Dian Fitri, dkk. 2014. Karakteristik Berpikir Kreatif siswa Kelas VII SMPN 1 Kragan dalam Memecahkan dan Mengajukan Masalah Matematika Materi Perbandingan Ditinjau dari Gaya Kognitif. JMEE. Vol.4, No.2, halaman 1-12, Desember 2014.

[2] BSNP. 2006. Standar Isi untuk Satuan Pendidikan Dasar dan Menengah, Standar Kompetensi dan Kompetensi dasar SMP/MTts. $P d f$. Jakarta.

[3] Hobri. 2009. Pembelajaran Matematika Berorientasi Vocational Skill dengan Pendekatan Kontekstual Berbasis Masalah Kejuruan. Malang: UM Press.

[4] Kamalia, Helmi. 2009. Hubungan antara gaya kognitif dan tingkat perkembangan konsep geometri berdasarkan teori Van Hiele Siswa Kelas VII SMP Negeri 2 Panji Tahun Ajaran 2008/2009. Skripsi tidak diterbitkan. Jember: FKIP Universitas Jember.

[5] Komarudin, dkk. 2014. Proses Berpikir Kreatif Siswa SMP dalam Pengajuan Masalah Matematika Ditinjau dari Gaya Kognitif Siswa (Studi Kasus pada Siswa Kelas VIII-H SMP Negeri I Sukoharjo Tahun Pembelajaran 2012/2013). Jurnal Elektronik Pembelajaran Matematika, Vol.2, No.1, halaman 29-43, Maret 2014.

[6] Moleong, Lexy J. 2001. Metodologi Penelitian Kualitatif. Bandung: PT Remaja Rosdakarya.

[7] Mustafa, Zainal. 2009. Mengurai Variabel hingga Instrumentasi. Yogyakarta: Graha Ilmu.

[8] Sasongko, Dimas Femy, dan Siswono, T. Y. E. 2013. Kreativitas Siswa dalam Pengajuan Soal Matematika Ditinjau dari Gaya Kognitif Field-Independent (FI) dan Field-Dependent (FD). MATHEdunesa, Vol.2, No.1

[9] Sukardi. 2011. Metodologi Penelitian Pendidikan Kompetensi dan Praktiknya. Jakarta: PT Bumi Aksara.

[10] Widoyoko, S. Eko Putro. 2013. Teknik Penyusunan Instrumen Penelitian. Yogyakarta: Pustaka Pelajar.

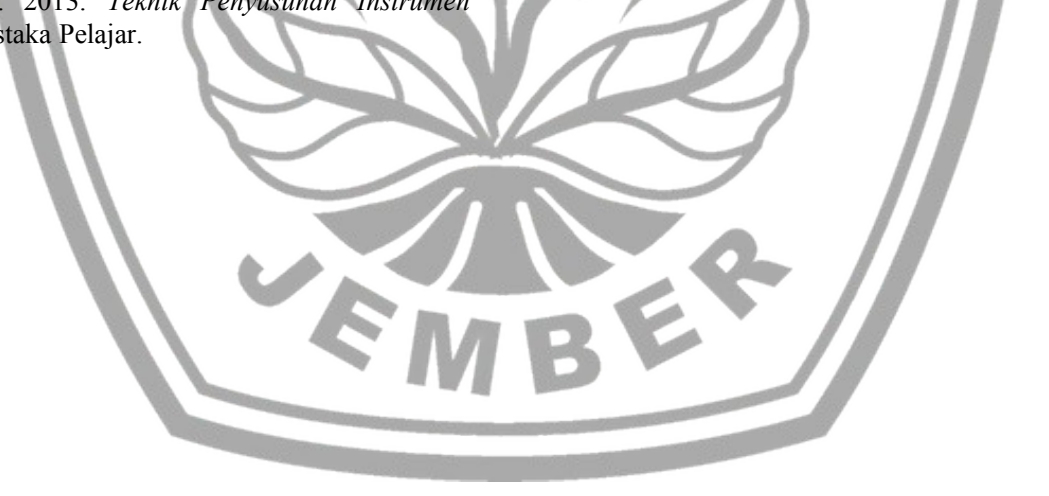

